\title{
Modelling for Hevea brasiliensis and Manihot esculenta plantations responses to climate change in Song Hinh District of Phu Yen province, Vietnam
}

\author{
Mai Phuong Pham ${ }^{1 *}$, Thi Hanh Tong ${ }^{2}$, Dinh Duy Vu ${ }^{1}$ and Quoc Khanh Nguyen ${ }^{1}$ \\ ${ }^{1}$ Vietnam - Russia Tropical Centre, Cau Giay district, Ha Noi, Vietnam \\ ${ }^{2}$ Le Quy Don Technical University, Bac Tu Liem district, Ha Noi, Vietnam
}

\begin{abstract}
The research aimed to evaluate the land potential for annual and perennial agricultural crops in Song Hinh district - Phu Yen province of Vietnam using integration of AHP -GIS technique based on the maximum limitation method of the FAO (Food and Agriculture Organization of the United Nations) and ecological requirements of planted crops rubber plant and cassava plant (Hevea brasiliensis and Manihot esculenta). Twenty social, economic and environmental parameters selected to analyze in the model. The results of the land evaluation showed that the high potential land of rubber plant is likely to increase by $51 \%$ by 2065 . Meanwhile, the high potential land of cassava plant is likely to increase by $32 \%$. The study used the climate change scenarios of the Intergovernmental Panel on Climate Change (IPCC) based on the most up-to-date results of climate models (under the CMIP5 project).
\end{abstract}

\section{Introduction}

Rubber plant (Hevea brasiliensis) is a tree indigenous to the tropical forests and the highest latex-bearing plant cultivated as the primary source of natural rubber. Challenges confronting the industry are fluctuating rubber prices, long immaturity, shortage of experienced tappers, potential threats of devastating diseases, with competition from other sources of natural rubber like Guayule and Dandelion [1]. Most of the cultivated rubber grown in the lowlands, between $15^{\circ} \mathrm{N}$ and $10^{\circ} \mathrm{S}$, where the climate is hot, humid and equable, with temperatures of $23-35^{\circ} \mathrm{C}$ and a well-distributed rainfall of $190-200 \mathrm{~cm}$ or more per year. Tapping begins when the trees reach 5-7 years old or when the tree girth reaches $50 \mathrm{~cm}$ [2]. Rubber tree were planted in Vietnam since 1892 in Southeast of Vietnam with the largest area and highest production. Due to rising oil price in recent years, the demand for natural rubber increased since the 1880s (http://iasvn.org/). Rubber tree cultivation is a major economic activity of South-East Asia and is expanding rapidly into areas with low and unreliable rainfall [3]. Midday leaf water potential of rubber trees was relatively stable throughout the year and did not drop significantly during the late dry season, displaying isohydric behavior. Soil and stem water isotope signatures along with rooting distributional patterns revealed that rubber trees

*Corresponding author: phamphuong911vh@gmail.com 
extracted water mainly from the top $30 \mathrm{~cm}$, and less from below $70 \mathrm{~cm}$ of the soil in late rainy season. During the late dry season, as the moisture in the middle soil layers $(30-70 \mathrm{~cm})$ was gradually depleted, the depth of water uptake shifted to deeper soil levels. This ability to take up a large proportion of shallow soil water after rainfall is likely the key feature enabling rubber trees to thrive through the period of greatest water demand. Rubber trees are able to adjust the allocation of resources and thus acclimate to the spatiotemporal changes to water conditions in the soil profile [4]. The expansion of rubber cultivation into drought prone areas calls for innovative management to increase the drought resistance of the trees [3]. Therefore, the study area selected is Song Hinh, weather of prolonged drought, and rubber trees are the choice.

In agricultural production, cassava plant (M. esculenta) has been increasingly asserted its important position in the world market. Cassava production has become a strategic commodity for many businesses and localities to develop economy especially in Phu Yen. Cassava production used in such manufacturing as starch, producing food, fertilizer, industrial technical alcohol [5]. Currently, output for this production is almost limitless.Phu Yen province is a tropical region with hilly topography is ideal for root crop cultivation. Cassava is a low labor and drought tolerant plan making it advantage for farmers in inclement condition. It is also known as the poverty alleviation trees. Recently, the local farmer of Song Hinh district have had a stable income from planting them. Expansion of cassava production has been relatively steady since 1980 with an additional push between the years 1988 to 1992 owing to the release of new improved varieties developed by the International Institute of Tropical Agriculture (IITA). National per capita production of cassava at 0.32 tons, and over 800 million people globally depend on cassava as a regular source of energy [5, 6]. This may be due to a greater reliance on cassava as it is drought tolerant, but it may also be due to an increase the level of cyanogenic glycosides. They are considered to have an important role in plant defense against herbivores due to bitter taste and release of toxic hydrogen cyanide upon tissue disruption [7]. The findings suggest that there are huge challenges for sustainable cassava intensification, specifically in identifying the needs for market diversification, dealing with emerging pests and diseases, and implementing adequate soil management practices. This is particularly challenging in a system that is driven by the need to maximize output with minimum investment [8].

Future climate change supposed to have different effects on various crops. Modeling results can be used to make appropriate management decisions and to provide farmers with alternative options for their farming system in responding to climate change [9]. Variability of agriculture production is due to the variability in weather conditions [10]. The lack of adaptive strategies to cope with this variability makes some countries highly vulnerable to extreme climate events and climate change. These studies can provide a rational to improved land use production in the context of local condition adaptation to climate change [11-13].

This study aimed to use integration of AHP-GIS technical to simulate potential cultivation areas of above-mentioned crops in Song Hinh district of Phu Yen province of Vietnam. This model is particularly well suited to evaluate the potential suitability according to requirement of these plants on natural conditions [14-19]. Our objectives are: (1) map the potential land for these crops base on economic-social-environmental assessment; (2) predict and simulate the potential cultivation land under future (2065); (3) analyze the spatial variability of these crops. 


\section{Materia and Methodology}

\subsection{Study area}

The study was carried out in Song Hinh district of Phu Yen province, Vietnam with tropical monsoon climate, hot and humid. There are two distinct seasons here: the rainy season from September to December and the dry season from January to August. The annual average temperature is $26.5^{\circ} \mathrm{C}$, the average annual precipitation is about $1,600-1,700 \mathrm{~mm}$. Planted area of cassava crop increase since 2015 was 6\% and reached 11.014 ha in 2019. Yield of cassava was highest in province and increase for 5 years was $16 \%$. Similar to cassava, the land area index of rubber plantation was highest in this district compared with others in province and reached 2.082 ha in 2019. Area of rubber plantation increased 89\% since 2015. Although climate change was the reason increasingly severe droughts affected people's living and agricultural production. Every year, the local people implemented many measures to struggle against drought with the spirit of overcoming difficulties. Over the years of fighting drought, people have a lot of creativity, solving the severity of the weather and saving crops in the dry season. In particular, farmers have effectively exploited water resources to struggle against drought, many cultivated areas have been saved [20].

\subsection{Data collection}

The digital elevation models (DEMs) data with resolution 30x30m were downloaded from http://srtm.csi.cgiar.org/ as available for terrain elevation. Surface analysis functions in ArcGIS 10.0 was used to build an elevation map and slopes. Soil factors: Soil type, soil texture, soil layer thickness, proportion of stones mixed in the soil, slope were collected from the Soil map of Phu Yen province (scale 1:100.000) as provided by the Ministry of Natural Resources and Environment (MONRE). Climatic factors: bio-climate parameters (annual Mean Temperature, annual Precipitation, number of dry months /year) from WorldClim-Global (ver.2) [21] was collected in spatial resolutions of 30s (1 km2). The climate change scenario was used on the basis of the 5th Assessment Report (AR5) of the Intergovernmental Panel on Climate Change (IPCC) using the most up-to-date results of climate models (under the CMIP5 project). Scenario are used in this study: Medium low greenhouse gas concentration (RCP4.5). The data mentioned above was used to map land potential for crops, as well as forecasts for the future.

The data of surveying through interviewing local people including:

- The data involved in the evaluation of economic efficiency such as: ( basic investment, annual investment, total income, net income, value of working days, capital efficiency) (Table 1).

- The data involved in the evaluation of social efficiency such as: $\left(\mathrm{I}_{1}\right.$ : Ability to ensure farmers' livelihoods), ( $\mathrm{I}_{2:}$ Is it consistent with the region's socio-economic development goals), ( $\mathrm{I}_{3}$ : Ability to create local labor force), ( $\mathrm{I}_{4}$ : Sustainability of land use types), $\left(\mathrm{I}_{5}\right.$ : The proportion of products that are products in the total output obtained) (Table 2).

- The data involved in the evaluation of environmental efficiency such as: flooding depth, period of a flood, water table (Table 4).

\subsection{Efficiency analysis of land use systems}

\subsubsection{Economic efficiency analysis}

Evaluate economic indicators according to Instruction for agricultural production land evaluation of Ministry of Science and Technology (MOST) of Vietnam (2012), the field data 
collection from farmer households (basic investment, annual investment, total income, net income, value of working days, capital efficiency) were the input data for economic analytical evaluations. Score of each product on each farmer household was calculated (Table 1).

Table 1. Decentralization of economic efficiency assessment [22]

\begin{tabular}{|c|l|c|c|c|c|c|c|c|}
\hline TT & $\begin{array}{c}\text { Assessment } \\
\text { hierarchy }\end{array}$ & $\begin{array}{c}\text { Basic } \\
\text { investment } \\
\mathbf{( 1 0 0 0} \text { VND) }\end{array}$ & $\begin{array}{c}\text { Annual } \\
\text { investment } \\
\mathbf{( 1 0 0 0} \text { VND) }\end{array}$ & $\begin{array}{c}\text { Total } \\
\text { income } \\
\mathbf{( 1 0 0 0} \\
\text { VND) }\end{array}$ & $\begin{array}{c}\text { Net } \\
\text { income } \\
\mathbf{( 1 0 0 0} \\
\text { VND) }\end{array}$ & $\begin{array}{c}\text { Value of } \\
\text { working } \\
\text { days (1000 } \\
\text { VND) }\end{array}$ & $\begin{array}{c}\text { Capital } \\
\text { efficiency } \\
\text { (times) }\end{array}$ & Score \\
\hline 1 & Very high (VH) & $>20.0$ & $>8.0$ & $>10.0$ & $>9.0$ & $>50$ & $>4.5$ & 5 \\
\hline 2 & High (H) & $15.0-20.0$ & $5.0-8.0$ & $5.0-10.0$ & $4.5-9.0$ & $30-50$ & $3.0-4.5$ & 3 \\
\hline 3 & Medium (M) & $10.0-15.0$ & $3.0-5.0$ & $2.0-5.0$ & $2.0-4.5$ & $20-30$ & $1.8-3.0$ & 2 \\
\hline 4 & Low (L) & $5.0-10.0$ & $2.0-3.0$ & $1.0-2.0$ & $1.0-2.0$ & $10-20$ & $1.3-1.8$ & 1 \\
\hline 5 & $\begin{array}{l}\text { Very low } \\
\text { (VL) }\end{array}$ & $<5.0$ & $<2.0$ & $<1.0$ & $<1.0$ & $<10$ & $<1.3$ & 0 \\
\hline
\end{tabular}

\subsubsection{Social efficiency analysis}

Social efficiency analysis is an important content to ensure the sustainable development of the land use chosen for cultivation to assess the extent and impacts of land use types on the social-condition. Indicators to be considered are listed in the Table 2 and also including in the questionnaires were sent to households.

Table 2. Social impact assessment of land use types [22]

\begin{tabular}{|c|c|c|c|}
\hline Indicator & Level & Category & Score \\
\hline \multirow{3}{*}{$\begin{array}{l}\text { I: Ability to ensure } \\
\text { farmers' livelihoods }\end{array}$} & Not ensure farmers' livelihoods & Unsustainable & 1 \\
\hline & Quite a bit to ensure farmers' livelihoods & Less sustainable & 2 \\
\hline & Ensure farmers' livelihoods & Sustainable & 3 \\
\hline \multirow{3}{*}{$\begin{array}{l}\text { I2: Agreement with the } \\
\text { region's socio-economic } \\
\text { development goals }\end{array}$} & $\begin{array}{l}\text { Not consistent with the region's socio- } \\
\text { economic development goals }\end{array}$ & Unsustainable & 1 \\
\hline & $\begin{array}{l}\text { Quite a bit to consistent with the region's socio- } \\
\text { economic development goals }\end{array}$ & Less sustainable & 2 \\
\hline & $\begin{array}{l}\text { Consistent with the region's socio-economic } \\
\text { development goals }\end{array}$ & Sustainable & 3 \\
\hline \multirow{3}{*}{$\begin{array}{l}\text { I3: Ability to create } \\
\text { local labor force }\end{array}$} & Not create local labor force & Unsustainable & 1 \\
\hline & Quite a bit to create local labor force & Less sustainable & 2 \\
\hline & Create local labor force & Sustainable & 3 \\
\hline \multirow{3}{*}{$\begin{array}{l}\text { I4: Sustainability of land } \\
\text { use types }\end{array}$} & Weak sustainability of land use types & Unsustainable & 1 \\
\hline & Moderate sustainability of land use types & Less sustainable & 2 \\
\hline & Sustainability of land use types & Sustainable & 3 \\
\hline \multirow{3}{*}{$\begin{array}{l}\text { I5: The proportion of } \\
\text { products that are } \\
\text { products in the total } \\
\text { output obtained }\end{array}$} & Weak proportion & Unsustainable & 1 \\
\hline & Moderate proportion & Less sustainable & 2 \\
\hline & High proportion & Sustainable & 3 \\
\hline
\end{tabular}

The results of analysis to assess social efficiency - of each land use types. Selection of appropriate land use types as a basis for the formulation of planning options and using land.

\subsubsection{Land potential evaluation for crops}

The study was conducted to map the potential land for cassava and rubber plants, using integration of GIS-AHP on FAO basing. Environmental factors were selected to process of land potential evaluation include: soil type, thickness, slope, mechanical composition, ability irrigation, precipitation, air humidity, air temperature, number of dry months, number of sunny hours (Table 4) 


\subsection{Analytic hierarchy process (AHP)}

Analytic hierarchy process (AHP) model based on expert judgement using scale of 1 to 9 that represent the weight of each criteria over the other with respect to the property [23-24]. Ten experts are invited to process to provide judgments on pair comparison question to determine which criteria affect to land-use suitability for each crop. Overall priorities can be made through synthesising or pooling together the judgement made in the pairwise comparisons. Consistency Ratio (CR) (<10 \%) was used to check the accuracy of comparisons [23].

Table 3. Nine-point scale using in expert judgement [23]

\begin{tabular}{|c|l|}
\hline $\begin{array}{c}\text { Intensity of } \\
\text { importance }\end{array}$ & \multicolumn{1}{c|}{ Judgments of verbal attribute labels } \\
\hline 9 & Absolute importance \\
\hline 7 & Very strongly importance or preferred \\
\hline 5 & Strong importance or strongly preferred \\
\hline 3 & Weak importance, moderately important or preferred \\
\hline $2,4,6,8$ & Intermediate values between adjacent judgments the two \\
\hline 1 & Equally preferred more important or preferred \\
\hline
\end{tabular}

Score for each criterion $\left(\mathrm{X}_{\mathrm{i}}\right)$ on each land mapping unit (LMU) was determined, important of criteria $i$ are converted to criteria weights $\left(\mathrm{W}_{\mathrm{i}}\right), i$ rang from 1 to $n$, where $n$ was the total number of criteria involved in the process. The weighted linear combination of $\mathrm{W}_{\mathrm{i}}$ and $\mathrm{X}_{\mathrm{i}}$ give suitability index SI for each land mapping unit. By above process, land-use suitability map is produced by score of each criterion and computed for each LMU. This process was done in ArcGIS 10.0 through the composite map of land mapping units using the formula in Eq (1).

$$
\mathrm{SI}=\sum_{i=1}^{n}\left(W_{i} \cdot \mathrm{X}_{\mathrm{i}}\right)
$$

\subsection{Geographic Information System (GIS)}

GIS is used to conduct the map of land suitability. The data of criteria were classified using the 4 levels $\left(\mathrm{S}_{1}, \mathrm{~S}_{2}, \mathrm{~S}_{3}, \mathrm{~N}\right)$ which had been determined via Instruction for agricultural production land evaluation of Vietnamese Standard TCVN 8409:2012 [22]. Weight of each criteria was obtained via local experts by questionnaire. The aim of this work was to create component maps in raster form. All raster layers were targeted in WGS84-Zone 48N and AHP acquired weights of all criteria have been applied. Land suitability of crop was mapped by overlay of raster component maps using ArcGIS 10.0 software. Finally, the map of land suitability for crops was obtained and classified into 4 categories $\left(\mathrm{SI}_{1}, \mathrm{SI}_{2}, \mathrm{SI}_{3}, \mathrm{~N}\right)$. According to the [25], the value of $\mathrm{SI}>80 \%$ was high suitable index $\left(\mathrm{SI}_{1}\right)$, followed by moderately suitable index ( $\left.\mathrm{SI}_{2}: 40 \%-80 \%\right)$, marginally suitable index $\left(\mathrm{SI}_{3}: 20 \%-40 \%\right)$, not suitable index (N $<20 \%)$.

\section{Result and discussion}

\subsection{Land potential evaluation}


Table 4. The weights of factors in land potential analysis of rubber and cassava plant in study area

\begin{tabular}{|c|c|c|c|c|c|c|}
\hline \multicolumn{7}{|c|}{ Rubbber plant } \\
\hline \multicolumn{2}{|c|}{ Factors } & $\begin{array}{c}\text { S1 } \\
\text { (Score: 100) }\end{array}$ & $\begin{array}{c}\text { S2 } \\
\text { (Score: 70) }\end{array}$ & $\begin{array}{c}\text { S3 } \\
\text { (Score: } 30)\end{array}$ & $\begin{array}{c}\mathrm{N} \\
\text { (Score: 15) }\end{array}$ & $\begin{array}{l}\text { Weight } \\
\text { (W) }\end{array}$ \\
\hline \multicolumn{2}{|c|}{$\begin{array}{l}\text { 1) Annual Mean Temperature } \\
\text { (celsius degree) }\end{array}$} & $>22$ & $19-22$ & $17-19$ & $<17$ & 0.089 \\
\hline \multicolumn{2}{|c|}{ 2) Annual Precipitation (millimeter) } & $>2300$ & $1900-2300$ & $\begin{array}{c}1100- \\
1900\end{array}$ & $<1100$ & 0.148 \\
\hline \multicolumn{2}{|c|}{$\begin{array}{l}\text { 3) Number of dry months / year } \\
\text { (month) }\end{array}$} & & & 1 & $>2$ & 0.064 \\
\hline \multirow{5}{*}{$\begin{array}{l}\text { 4) Soil } \\
\text { characteristics }\end{array}$} & Soil type & $\begin{array}{l}\text { Ft, Fk, Fu, } \\
\text { Fv, Fn }\end{array}$ & $\begin{array}{l}\text { Fe, Fj, Fs, } \\
\text { Fp, X }\end{array}$ & $\begin{array}{l}\text { Fa, Fq, } \\
\text { Xa }\end{array}$ & $\begin{array}{c}\text { Other } \\
\text { soil type }\end{array}$ & 0.247 \\
\hline & Slope (degree) & $<8$ & $>8-15$ & $15-20$ & $>20$ & 0.065 \\
\hline & $\begin{array}{l}\text { Soil depth } \\
(\mathrm{cm})\end{array}$ & $>100$ & $>70-100$ & $>50-70$ & $<50$ & 0.078 \\
\hline & $\begin{array}{l}\text { Proportion of } \\
\text { stones mixed } \\
\text { in the soil (\%) }\end{array}$ & $<30$ & $30-50$ & $>50$ & $>70$ & 0.062 \\
\hline & Soil texture & $\begin{array}{l}\text { Loam, } \\
\text { Clay loam }\end{array}$ & $\begin{array}{c}\text { Sandy loam, } \\
\text { heavy clay } \\
\text { loam }\end{array}$ & Clay & Sandy & 0.081 \\
\hline \multicolumn{2}{|l|}{ 5) Flooding } & $\begin{array}{l}\text { No } \\
\text { Flooding }\end{array}$ & & & $\begin{array}{l}\text { Flooding } \\
\text { in } \\
\text { rainning } \\
\text { season }\end{array}$ & 0.081 \\
\hline \multicolumn{2}{|c|}{ 6) Water table (meter) } & $>2$ & $>1.5-2$ & $1-1.5$ & $<1$ & 0.082 \\
\hline \multicolumn{7}{|c|}{ Note: $C R=0.001$} \\
\hline \multicolumn{7}{|c|}{ Cassava plant } \\
\hline \multicolumn{2}{|c|}{ Factors } & $\begin{array}{c}\text { S1 } \\
\text { (Score: 100) }\end{array}$ & $\begin{array}{c}\text { S2 } \\
\text { (Score: 70) }\end{array}$ & $\begin{array}{c}\text { S3 } \\
\text { (Score: } 30)\end{array}$ & $\begin{array}{c}\text { N } \\
\text { (Score: 15) }\end{array}$ & $\begin{array}{l}\text { Weight } \\
\text { (W) }\end{array}$ \\
\hline \multicolumn{2}{|c|}{$\begin{array}{l}\text { 1) Annual Mean Temperature } \\
\text { (celsius degree) }\end{array}$} & $>19-22$ & $>17-19$ & $\begin{array}{l}>22> \\
15-27 \\
\end{array}$ & $<15$ & 0.087 \\
\hline \multicolumn{2}{|c|}{ 2) Annual Precipitation (millimeter) } & $\begin{array}{l}>1500- \\
1900\end{array}$ & $\begin{array}{c}>1100- \\
1500\end{array}$ & $\begin{array}{c}>1900- \\
2300\end{array}$ & $\begin{array}{l}>2300 \\
<1100\end{array}$ & 0.157 \\
\hline \multicolumn{2}{|c|}{$\begin{array}{l}\text { 3) Average annual sunny hours } \\
\text { (hours) }\end{array}$} & $>2500$ & $\begin{array}{c}>2000- \\
2500\end{array}$ & $\begin{array}{l}>1500- \\
2000\end{array}$ & $<1500$ & 0.056 \\
\hline \multirow{4}{*}{$\begin{array}{l}\text { 4) Soil } \\
\text { characteristics }\end{array}$} & Soil type & $\begin{array}{l}\text { Ft, Fk, Fu, } \\
\text { Fv, Fn, } \\
\text { Ru, Rv, Fj, } \\
\text { Fs }\end{array}$ & $\begin{array}{l}\text { Fa, Fq, Fp, } \\
\text { Fs, X, Pbe, } \\
\text { Pbc, Py }\end{array}$ & $\begin{array}{c}\mathrm{Pf}, \mathrm{Hk}, \\
\mathrm{Hu}, \mathrm{Hj}, \\
\mathrm{Hs}, \mathrm{Ha}, \\
\mathrm{Hq}\end{array}$ & $\begin{array}{l}\text { Other } \\
\text { soil type }\end{array}$ & 0.250 \\
\hline & Slope (degree) & $>3-8$ & $\begin{array}{c}0-3,>8- \\
15\end{array}$ & $>15-25$ & $>25$ & 0.056 \\
\hline & Soil texture & Clay & Sandy loam & Loam & Sandy & 0.069 \\
\hline & Soil depth (cm) & $>70$ & $>50-70$ & $>30-50$ & $<30$ & 0.069 \\
\hline \multirow{2}{*}{ 5) Flooding } & $\begin{array}{l}\text { Flooding depth } \\
\text { (cm) }\end{array}$ & $\begin{array}{l}\text { No } \\
\text { Flooding }\end{array}$ & & $<30$ & $<60$ & 0.068 \\
\hline & Period of a flood & $\begin{array}{l}\text { No } \\
\text { Flooding }\end{array}$ & $<1$ day & $<5$ days & $\begin{array}{c}\text { Over } 5 \\
\text { days }\end{array}$ & 0.071 \\
\hline \multicolumn{2}{|c|}{ 6) Water table (meter) } & $<2$ & $>1.5-2$ & $1-1.5$ & $<1$ & 0.111 \\
\hline
\end{tabular}


The data from detailed interviews with 10 experts and local farmer were determined the factors effect on each crop growing, Table 4 showed that there were 10 factors (major factors and sub-factors) obtained by council of focus group discussion. In the section of evaluation for rubber tree in Table 4 , soil tyle (0.247) has the highest weighting, followed by annual precipitation $(0.148)$, annual mean temperature $(0,089)$. The consistency ratio $(\mathrm{CR})$ of the matrix was 0.001 . Land potential map for rubber tree base on environmental factors showed in Fig 3. In the section of evaluation for cassava plants in Table 4, soil type played major roles in describing the cassava potential land for with the highest weighting $(0.25)$, followed by annual precipitation (0.157), water table (0.111). The consistency ratio (CR) was 0.023 . Thus, soil type was essential and major factor to determine the potential of land for crops. Land potential map for cassava plants base on environmental factors showed in Fig 1. The results scoring of the economic - social - environmental efficiency were provided the potential map (Fig. 2, 4). Based on this index, two of the top communes in Song Hinh district, namely Ea Bar and Ea ly communes that were the largest and most developed sites in study area.

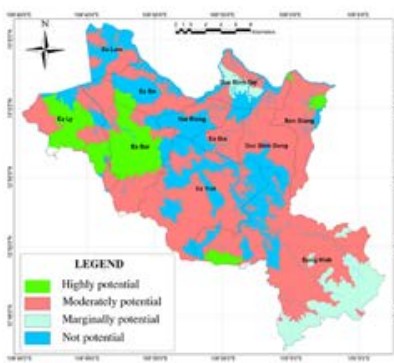

(A)

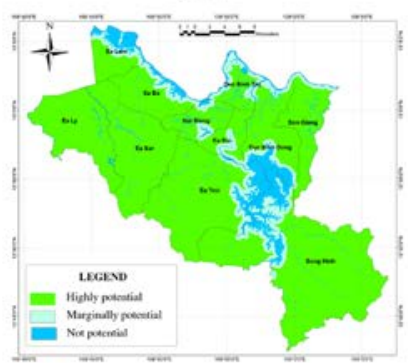

(D)

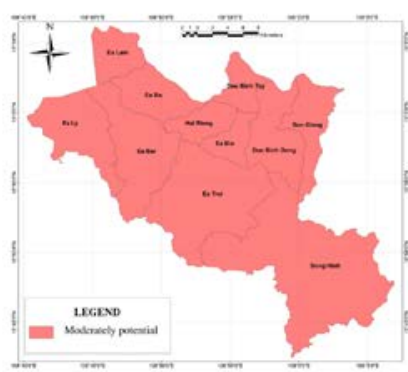

(G)

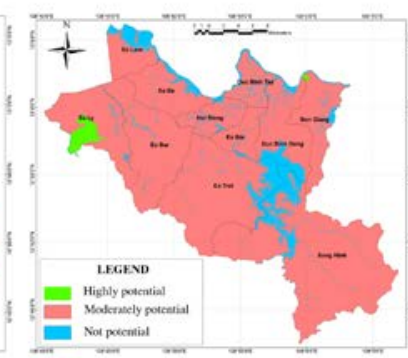

(B)

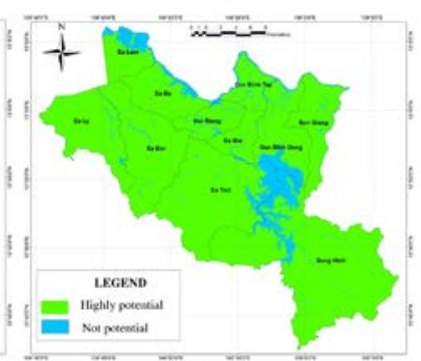

(E)

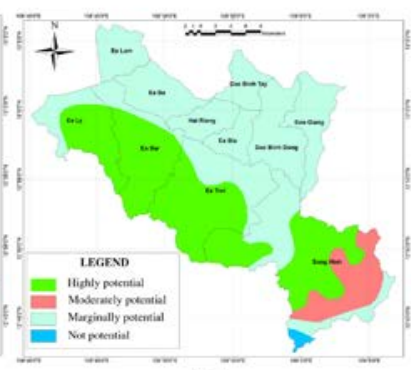

(H)

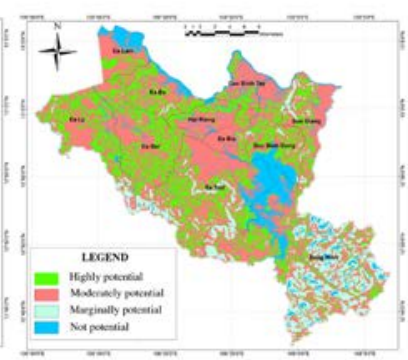

(C)

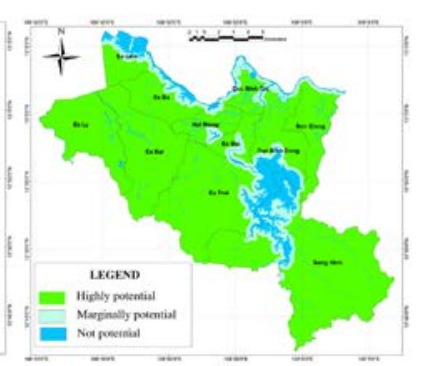

(F)

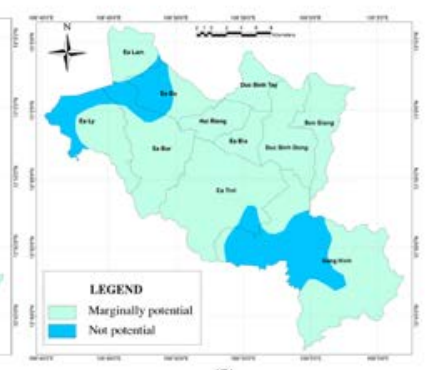

(I)

Fig. 1. Land potential map for cassava base on environmental factors.

A: Annual Mean Temperature; B: Annual Precipitation; C: Soil type; D: Slope; E: Soil texture; F: Soil depth; G: Flooding depth; H: Period of a flood. 


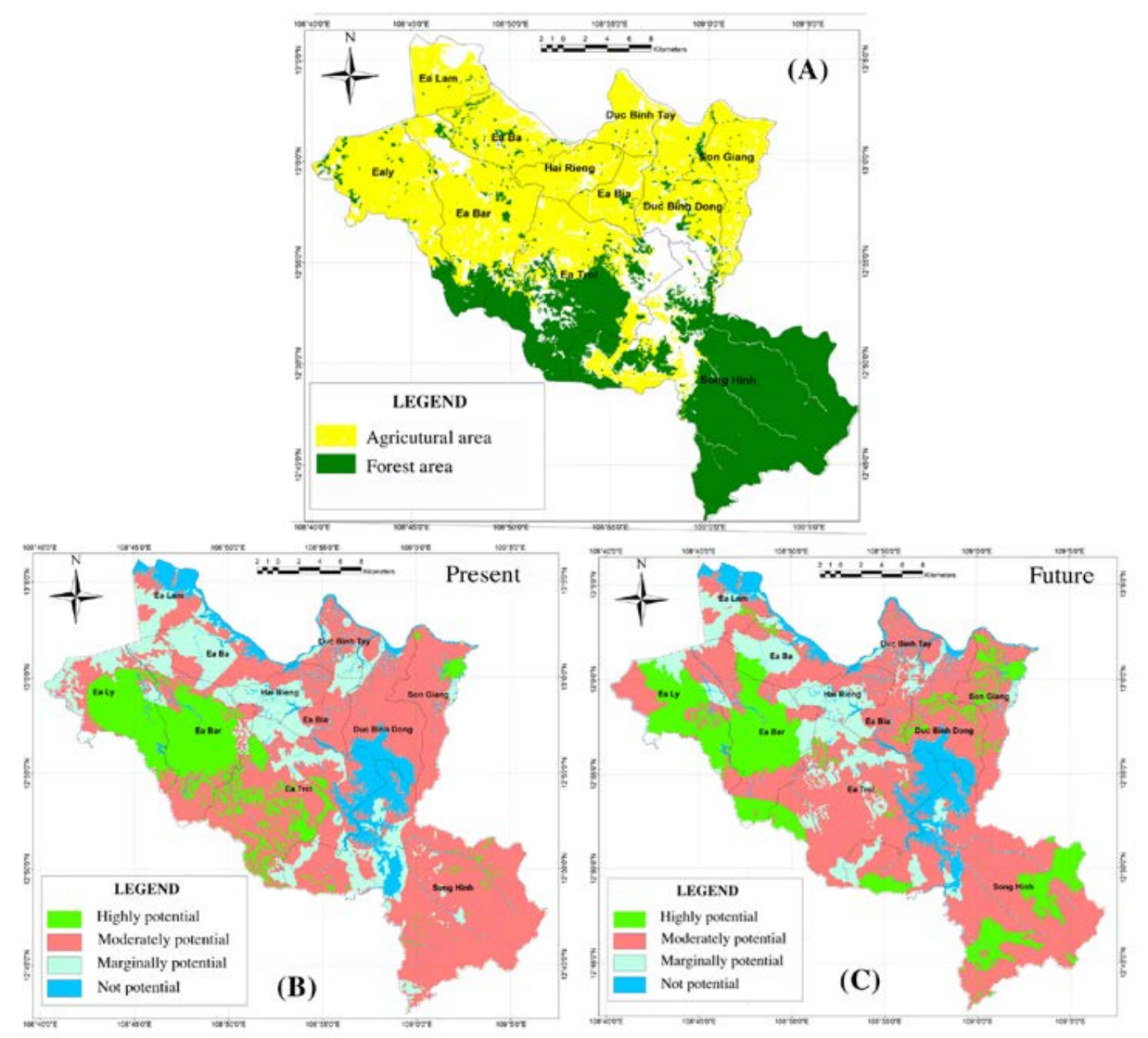

Fig. 2. Land potential map for cassava plant in Song Hinh, Phu Yen province, Vietnam

(A: Agricultural and forest land in study area), (B: Land potential map for cassava at present time),

(C: Land potential map for cassava in future 2065) 


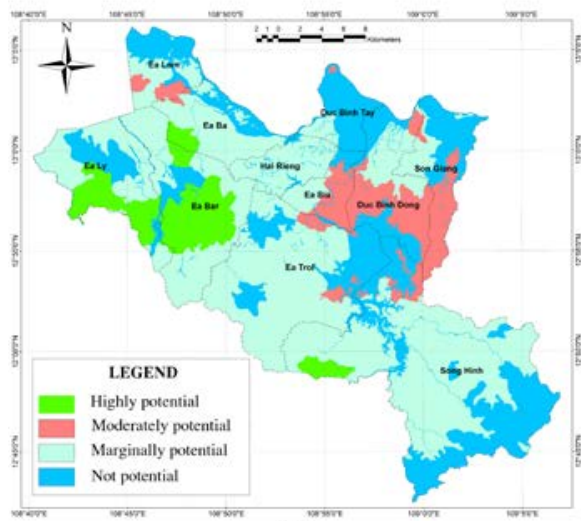

(A)

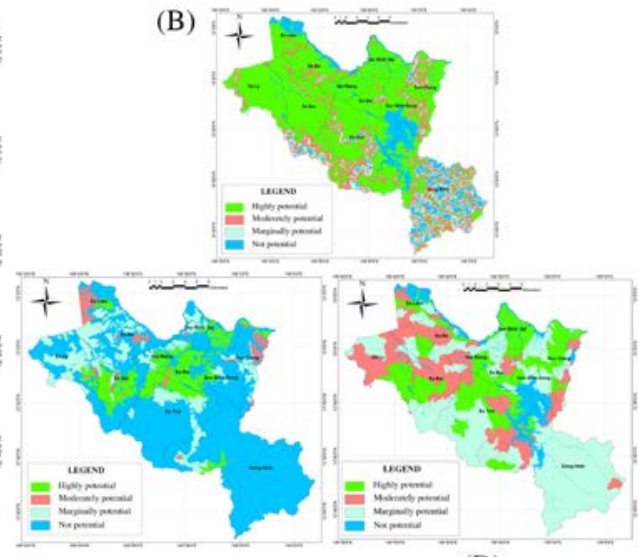

(C)
(D)

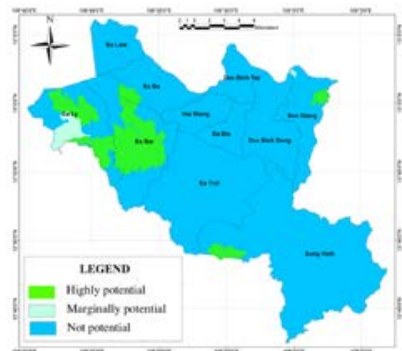

(E)

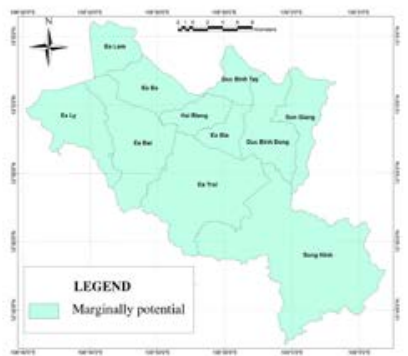

( $\mathrm{H})$

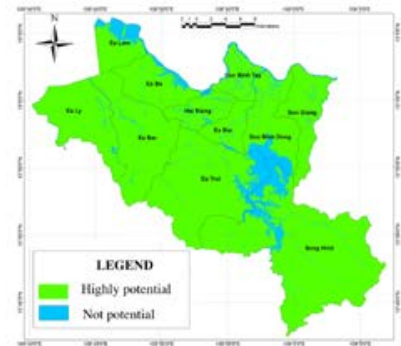

(F)

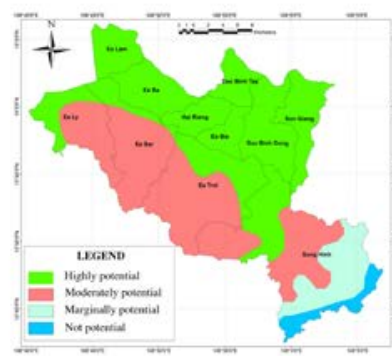

(I)

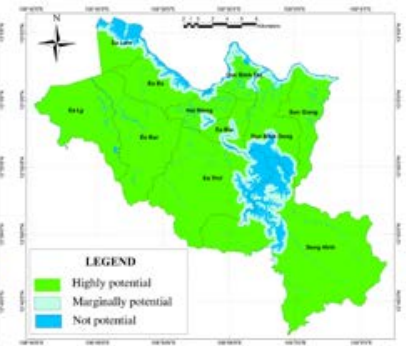

(G)

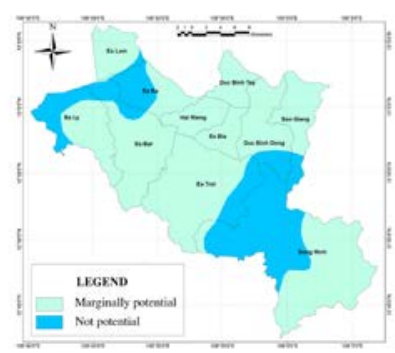

(J)

Fig. 3. Land potential map for rubber plant base on environmental factors

A: Annual Mean Temperature; B: Annual Precipitation; C: Number of dry months; D: Soil type; E: Slope (degree); F: Soil depth; G: Proportion of stones mixed in the soil; H: Soil texture;

I: Flooding; J: Water table 


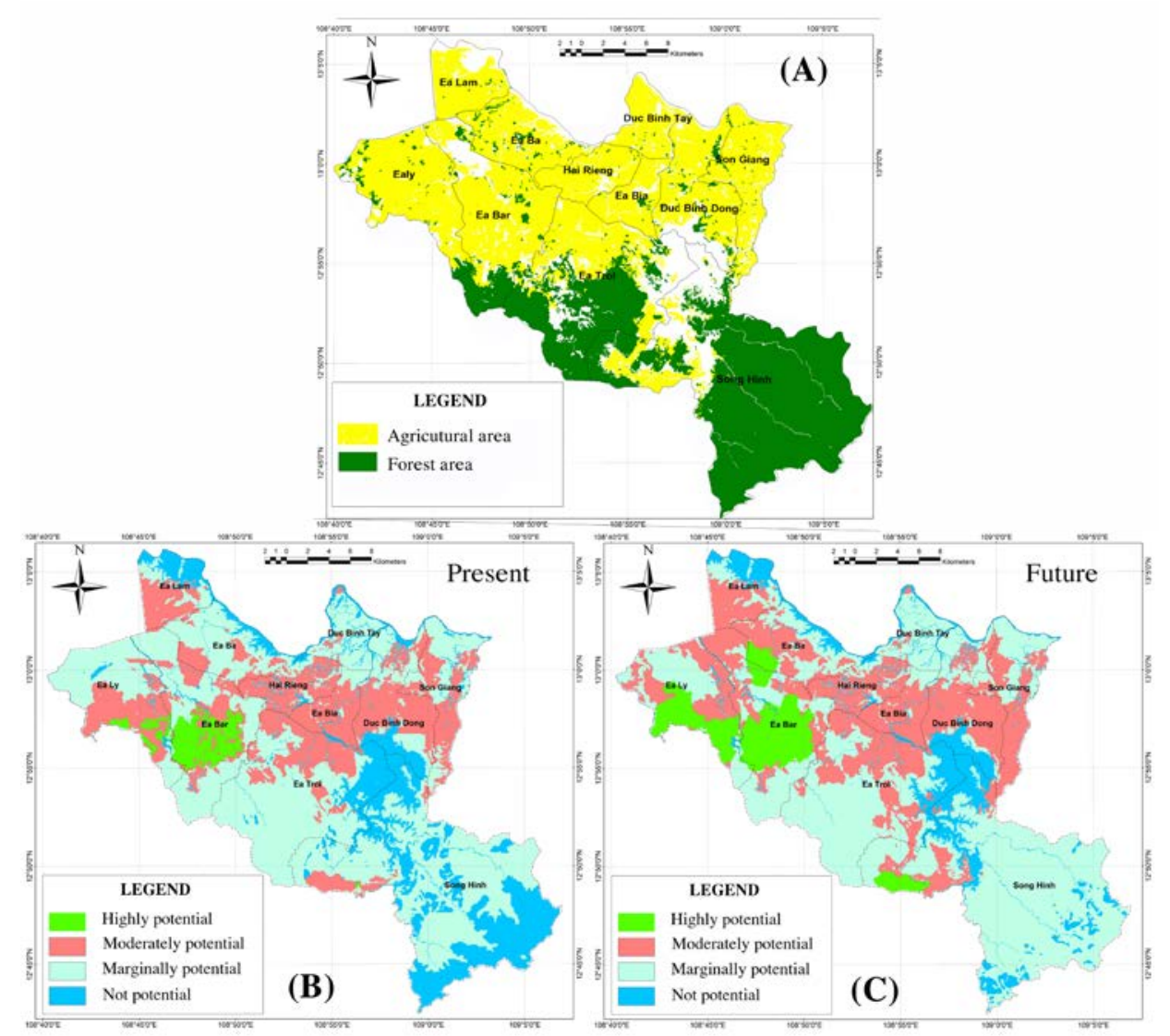

Fig. 4. Land potential map for rubber plant in Song Hinh, Phu Yen province, Vietnam

(A: Agricultural and forest land in study area), (B: Land potential map for rubber at present time),

(C: Land potential map for rubber in future 2065)

\subsection{Land potential for cassava and rubber plants under climate change}

Climate is considered as the primary important factor for agriculture that has motivated important change of research during the last decade. Climate change have effected on agricultural production's system in Phu Yen province. Thus, drought-loving crops have been selected for planting in many districts for many years. In particular, rubber trees and cassava are considered for the highest economic efficiency compared with the current cropping systems in the district. We considered the changing of climate in future 2065 year with the higher of temperature and precipitation, the higher of extreme climatic factors such as flooding and drought. We special considered soil characteristics, water table have no changing in future 2065 due to handle by future technology. According to scenarios (RCP4.5): annual average precipitation increase $13.4 \%$ in 2065 . Likewise, annual average temperature increase $1.3 \%$ in 2065. The drought will increase by an average of 1 month per year. Fig 2 and Fig 4 revealed that the potential area for these crops will not be threatened. The results of the land evaluation showed the high potential land of rubber plant is likely to increase by $51 \%$ by 2065. Meanwhile, the high potential land of cassava plant is likely to increase by $32 \%$. Cassava plantation area is likely to expand towards the forest land (Fig 2). Thus, our findings reflected the trend of the two trees actually struggle against the climate change effects. Taking adaptive action to avoid the damages and capitalize on the opportunities presented by climate 
change, this study is an important suggestion for spatial development planning of potential crops.

\section{Conclusions}

The result of this study showed that both types of plants provide high value, higher possibility to resist drought drought tolerance with less laborious care, that assessed suitability for environmental, economic and social conditions of the district. Model included the map of cassava and rubber land potential and the map of agro-forestry land which be used to compare and assess the trend of potential crops development in spatial. Assessment for 2065 according to scenarios RCP4.5 of the Intergovernmental Panel on Climate Change (IPCC) using the most up-to-date results of climate models (under the CMIP5 project), some potential areas moderately likely shift to a higher potential for the two plants in 2065 year. This reflects the reliable local policies in proposing current cropping systems. Three critical problems in assessment were considered in this study: (1) economic efficiency analysis, (2) social efficiency analysis, (3) evaluation of potential land using the variable of environmental factors. This logical approach has been resolved based on GIS and AHP to developed the strategy and to solve these problems.

We are grateful to Institute of Tropical Ecology of Vietnam - Russia Tropical Centre. We appreciate an administration of Song Hinh district - Phu Yen province. Special thanks to forest managers at Song Hinh Protected Forest supported for our survey.

A survey was supported from the project E 1.2 by Vietnam - Russia Tropical Centre, Ha Noi, Vietnam for 2020 year.

\section{References}

1. T.S. Heng, G.K. Joo, In Encyclopedia of Applied Plant Sciences (Second Edition) (2017)

2. T. H. Chua, In World Crop Pests, 7, 395-399 (1997)

3. C. Clermont-Dauphin, C. Dissataporn, N. Suvannang, P. Pongwichian, J.L. Maeght, C. Hammecker, C. Jourdan, Agronomy for Sustainable Development, 38(6), 1-10 (2018)

4. W. Liu, J. Li, H. Lu, P. Wang, Q. Luo, W. Liu, H. Li, Ecohydrology, 7(4), 1234-1244 (2014)

5. C.N. Anyanwu, C.N. Ibeto, S.L. Ezeoha, N.J. Ogbuagu, Renewable Energy, 81, 745752 (2015)

6. FAOSTAT. Online statistical database of the food and agriculture Organization (2013) http://faostat.fao.org [accessed 20.05.13

7. R. Vandegeer, R.E. Miller, M. Bain, R.M. Gleadow, T.R. Cavagnaro, Functional Plant Biology, 40(2), 195-200 (2013)

8. D.P. Le, R.A. Labarta, S. de Haan, M. Maredia, L.A. Becerra, L. Nhu, T. Ovalle, V. Nguyen, N. Pham, H. Nguyen, H. Nguyen, L. Le, H.H. Le, HH. 2019. Characterization of cassava production systems in Vietnam. Working Paper. CIAT Publication No. 480. International Center for Tropical Agriculture (CIAT). Hanoi, Vietnam. 54 p. (2019)

9. Y. Wang, Z. Tan, G. Sun, The Impact of Climate Change on the Potential Suitable Distribution of Major Crops in Zambia and the Countermeasures. In International Conference on Computer and Computing Technologies in Agriculture (pp. 460-472) (2014) 
10. P.J.M. Cooper, J. Dimes, K.P.C. Rao, Agriculture, Ecosystems \& Environment, 126(1), 24-35 (2008)

11. J. Thurlow, T. Zhu, X. Diao, Review of Development Economics 16(3), 394-411 (2012)

12. S.M. Howden, J.F. Soussana, F.N. Tubiello, Proceedings of the National Academy of Sciences, 104(50), 19691-19696 (2007)

13. L. You, S. Wood, U. Wood-Sichra, Agricultural Systems, 99(2), 126-140 (2009)

14. J.G. Malczewski, multicriteria decision analysis, pp. 3-260. John Wiley \& Sons, Canada (1999)

15. H. Akıncı, A.Y. Özalp, B. Turgut, Computers and electronics in agriculture, 97, 71-82 (2013)

16. M. Bagheri, W.N.A. Sulaiman, N. Vaghefi, Journal of coastal conservation, 17(1), 110 (2013)

17. A. Bozdağ, F. Yavuz, A.S. Günay, Environmental Earth Sciences, 75(9), 813 (2016)

18. J. Seyedmohammadi, F. Sarmadian, A.A. Jafarzadeh, R.W. McDowell, Geoderma, 352, 80-95 (2019)

19. J. Zhang, Y. Su, J. Wu, H. Liang, Computers and Electronics in Agriculture, 114, 202211 (2015)

20. Phu Yen Statistics Office. Statistical Yearbook of Phu Yen Province. Statistics publisher. (2012)

21. R.J. Hijmans, S.E. Cameron, J.L. Parra, P.G. Jones, A. Jarvis, Inter J Clima, 25(15), 1965-1978 (2005)

22. Ministry of Natural Resources and Environment. Climate change and sea level rise scenarios for Vietnam (2016)

23. T.L. Saaty, International journal of services sciences, 1(1), 83-98 (2008)

24. N. Saardchom, 5(2), 163-179 (2012)

25. FAO, World soil resources report 73. FAO, Rome, Italy (1993) 